\title{
Adaptive search for a PEM fuel cell maximum net power
}

\begin{abstract}
Supply method of the fuel cell cathode side significantly affects the durability and efficiency of the hydrogen energy conversion. A fuel cell is a stochastic object. The paper presents air flow control of the PEM fuel cell in order to find and hold the maximum value of the net power produced by the fuel cell stack, regardless of changes of the parameters of the object of control and its outer environment. The Application of an adaptive extremum control with bi-parameter identification provide automatic adjustment of the parameters of a controller to the changing characteristics of an object. The adaptive algorithm contains a number of variables and signals that support the estimation process. The quality and speed of finding an optimal point depends on their values.
\end{abstract}

Key words: PEM fuel cell, adaptive control, control algorithm

\section{Adaptacyjne poszukiwanie optimum mocy netto systemu ogniw paliwowych PEM}

Sposób zasilania w tlen strony katodowej ogniwa paliwowego istotnie wplywa na jego żywotność i efektywność wykorzystania energii chemicznej wodoru. Ogniwo paliwowe jest obiektem stochastycznym. W artykule opisano sterowanie powietrzem zasilajacym ogniwo $w$ celu określenia i stabilizacji pracy systemu w punkcie maksymalnej mocy netto bez względu na zmieniające się właściwości ogniwa paliwowego i jego otoczenia. Zastosowanie adaptacyjnego sterowania ekstremalnego z identyfikacja dwuparametryczną umożliwia dostosowanie się algorytmu sterowania do aktualnej charakterystyki ogniwa paliwowego. W algorytmie adaptacyjnym istnieje wiele zmiennych i sygnałów wspomagajacych proces estymacji. Jak wykazano w artykule od ich wartości zależy jakość i szybkość odnajdywania punktu optymalnego.

Słowa kluczowe: ogniwo paliwowe PEM, sterowanie adaptacyjne, algorytm sterujacy

\section{Introduction}

Nowadays in every area of life, we can see aspirations for enhancing the productivity, efficiency and better use of feedstock to produce all kinds of products. These trends are of great importance in an energy sector. As a result of shrinking fuel resources, people are forced to use them economically. In recent decades, scientists have discovered many methods of efficient use of energy. However, even more important than better and cheaper technologies are revolutionary trends in designing hardware of common use thanks to which technical innovations are combined together and applied in practice. An example of such a facility is the Nexa fuel cell system that combines the latest achievements in fuel cells, brushless DC engines and effective control.

Furthermore, it turns out that fuel cell systems can be optimized to obtain maximum efficiency. This can be done in many ways. Proper selection of components to build such a system and their effective control enable these objectives to be achieved. This work will present the results of the impact of airflow on the power generated by the PEM fuel cell. The argument that using an adaptation function in a fuel cell control algorithm helps find an operating point with maximum net power will be demonstrated, too. This means the best use of the chemical energy contained in fuel.

\section{The idea of the fuel cells air supply control}

The supply of oxygen to the cathode is one of the key factors in effective fuel cell control. When current is drawn from a fuel cell, the air supply system should replace the reacted oxygen. Otherwise the cathode will suffer from oxygen starvation, which damages the stack and limits the power

\section{Wprowadzenie}

W każdej dziedzinie życia można obecnie zaobserwować dążenia związane ze zwiększaniem wydajności, sprawności czy lepszym wykorzystaniem substratów do produkcji wszelkiego rodzaju wyrobów. Tendencje te mają ogromne znaczenie w sektorze energetycznym. Na skutek kurczenia się zasobów paliw kopalnianych ludzie są zmuszeni do oszczędnego korzystania z nich. W ciągu ostatnich kilkudziesięciu lat naukowcy odkryli wiele metod efektywnego wykorzystywania energii. Jednak jeszcze większe znaczenie niż coraz lepsze i tańsze technologie mają rewolucyjne trendy w projektowaniu sprzętu powszechnego użytku, dzięki którym techniczne nowinki są ze sobą łączone i stosowane w praktyce. Przykładem takiego obiektu jest system ogniw paliwowych Nexa łączący najnowsze osiągnięcia w dziedzinie ogniw paliwowych, silników bezszczotkowych prądu stałego i efektywnego sterowania.

Jak się okazuje, również systemy ogniw paliwowych można optymalizować w celu uzyskiwania jak największej sprawności. Można to czynić wieloma sposobami. Odpowiedni dobór komponentów do budowy takiego systemu oraz efektywne sterowanie nimi umożliwiają realizację takich celów. W tej pracy będą przedstawione wyniki badań wpływu wydatku powietrza na moc generowaną przez ogniwo paliwowe typu PEM. Będzie udowodniona również teza, że wprowadzenie do algorytmu sterowania ogniwem paliwowym funkcji adaptacji pozwala na odnalezienie punktu pracy z maksymalną mocą netto. Oznacza to najlepsze wykorzystanie energii chemicznej zawartej w paliwie. 
response of the fuel cell. Also, adequate water management is very important for performance and safe operation of the fuel cell [4]. The solution to this problem is to humidify air, hydrogen or both of these components before entering the fuel cell. Airflow functions as an internal cooling system. All this testifies to the immense role played by an air supply system in fuel cells. Optimizing airflow conditions can contribute to improving the system performance increasing power and life.

While a receiver is supplied with power by the fuel cell stack, i.e. the reactions in the fuel cells proceed, the oxygen from the air supplied to fuel cell cathode is consumed. Let us define the momentary air excess coefficient $\lambda$ as:

$$
\lambda=\frac{\mathrm{W}_{\text {air, in }}}{\mathrm{W}_{\text {air, reacted }}}[-]
$$

where $\mathrm{W}_{\text {air,in }}$ is the supplied air flow measured by means of a volumetric flow meter. $\mathrm{W}_{\text {air,eacted }}$ is the useful airflow, actually needed for chemical reactions, calculated on the basis of the produced current $\mathrm{I}_{\mathrm{st}}$ and the following electrochemical equation:

$$
\begin{gathered}
\mathrm{W}_{\text {air,reacted }}=\frac{\mathrm{M}_{\mathrm{air}}}{\mathrm{q}_{\mathrm{O}_{2}}} \cdot \frac{\mathrm{nI}_{\mathrm{st}}}{\mathrm{F} \cdot 4} \quad\left[\frac{\mathrm{kg}}{\mathrm{s}}\right] \\
\mathrm{W}_{\text {air,reacted,NEXA }}=1,68 \cdot 10^{-5} \cdot \mathrm{I}_{\mathrm{st}}\left[\frac{\mathrm{kg}}{\mathrm{s}}\right]=0,86 \cdot \mathrm{I}_{\mathrm{st}}[\mathrm{slpm}]
\end{gathered}
$$

where $\mathrm{n}$ is the number of cells in the fuel cell stack, $\mathrm{F}$ is the Faraday's constant (96485 C), $\mathrm{M}_{\text {air }}$ is molar mass of the air, and $\mathrm{q}_{\mathrm{O} 2}$ is the volume fraction of oxygen in the air.

The hydrogen and air supply in a complete fuel cell system still remains one of the most important problems to be solved before launching vehicles powered by fuel cells into the market. A freestanding stack of fuel cells has got very good performance characteristics, but if the required airflow and its pressure are not provided, these properties will never be achieved in vehicle applications. Moreover, the air supply system based on an electric motor/compressor system brings a great load into the efficiency of the entire fuel cell system [3]. Thus, optimization of work in an electric motor/ compressor system, and particularly the strategy of control in such a system, is an essential condition to commercialize fuel cell powered vehicles.

For high-pressure cells, the optimal value of an air excess coefficient $\lambda$ is independent of a cell load degree. Pukrushpan [2] examined the impact of an air excess coefficient on the net power of high-pressure cells (Fig. 1). For certain stack current, the stack voltage increases with increasing airflow rate to the stack since the cathode oxygen partial pressure increases. High oxygen excess ratio, and thus high oxygen partial pressure, improves $\mathrm{P}_{\text {st }}$ and $\mathrm{P}_{\text {net }}$. However, after an optimum value of $\lambda_{\mathrm{O} 2}$, further increase will cause excessive increase of compressor power and, thus deteriorate the system net power. Air compressor power consumption $\mathrm{P}_{\mathrm{cm}}$ was the only parasitic loss considered in this study

\section{Idea sterowania zasilaniem powietrzem ogniw paliwowych}

Zasilanie w tlen katody ogniwa paliwowego jest jednym z kluczy do sukcesu w efektywnym sterowaniu ogniwem paliwowym. Wynika to z wielu zadań, jakie pełni powietrze w układach tego typu. Kiedy prąd jest pobierany z ogniwa, konieczne jest, aby system zasilania w powietrze szybko uzupełniał zużyty tlen. W przeciwnym razie katoda ogniwa ucierpi w wyniku nadmiernego zubożenia w tlen, które może przyczynić się do jej uszkodzenia i w ten sposób do ograniczenia mocy wytwarzanej przez ogniwo [4]. Także odpowiednia gospodarka wodna jest bardzo ważna ze względu na osiągi i bezpieczną pracę ogniwa. Rozwiązaniem tego problemu jest nawilżanie powietrza, wodoru lub obu tych składników przed wprowadzeniem ich do ogniwa paliwowego. Wraz z powietrzem zostaje odprowadzona z ogniwa do otoczenia część ciepła wydzielanego w egzotermicznych reakcjach w nim zachodzących. Wszystko to świadczy o ogromnej roli, jaką pełni układ zasilania w powietrze w ogniwach paliwowych. Optymalizując warunki przepływu powietrza, można przyczynić się do poprawy osiągów systemu (zwiększyć moc, przedłużyć trwałość ogniwa).

Podczas poboru prądu elektrycznego z ogniwa paliwowego wykorzystywany jest tlen zasilający katodę. Wprowadzamy zatem pojęcie chwilowego współczynnika nadmiaru powietrza $\lambda$-wzór (1).

Wartość wydatku powietrza na wlocie do katody $\mathrm{W}_{\text {pow,wlot }}$ może być zmierzona za pomocą objętościowego przepływomierza powietrza.

Wartość powietrza potrzebnego do reakcji $\mathrm{W}_{\text {pow,reakcji }}$ jest obliczana z natężenia prądu stosu $\mathrm{I}_{\mathrm{st}}$ za pomocą elektrochemicznego równania (2), gdzie: $\mathrm{n}$ - liczba ogniw w stosie, $\mathrm{F}$ liczba Faraday'a (96485 C), $\mathrm{M}_{\text {pow }}$ - masa molowa powietrza, $\mathrm{q}_{\mathrm{O} 2}$ - objętościowy udział tlenu w powietrzu.

Zasilanie wodorem i powietrzem kompletnego systemu ogniw paliwowych ciągle pozostaje jednym z najważniejszych problemów do rozwiązania przed wprowadzeniem na rynki komercyjnych pojazdów zasilanych ogniwami paliwowymi. Wolnostojący stos ogniw paliwowych ma bardzo korzystne charakterystyki osiągów, ale gdy wymagany przepływ powietrza i jego ciśnienie nie są zapewnione, te właściwości nigdy nie będą osiągnięte w samochodowym zastosowaniu. Ponadto, system zasilania powietrzem oparty na zespole silnik/sprężarka wnosi duże obciążenie do sprawności całego systemu ogniw paliwowych [3]. Tak więc optymalizacja pracy zespołu silnik/sprężarka, a szczególnie strategia sterowania takim zespołem, stanowi niezbędny warunek komercjalizacji pojazdów zasilanych ogniwami paliwowymi.

Dla ogniw wysokociśnieniowych optymalna wartość współczynnika nadmiaru powietrza $\lambda$ jest niezależna od stopnia obciążenia ogniwa. Pukrushpan [2] wykonał badania wpływu współczynnika nadmiaru powietrza na moc netto ogniwa wysokociśnieniowego (rys. 1). Duży wydatek powietrza, a w wyniku tego wysoka wartość współczynnika $\lambda$, poprawia moc stosu ogniw $\mathrm{P}_{\text {st }}$ i moc netto $\mathrm{P}_{\text {net }}$. Jednak po przekroczeniu optymalnej wartości następuje bardzo szyki 


$$
\mathrm{P}_{\text {net }}=\mathrm{P}_{\mathrm{st}}-\mathrm{P}_{\mathrm{cm}}
$$

The author concluded that the optimal air excess coefficient is $\lambda_{\mathrm{O} 2}=2$ for a selected compressor and applied a single parametric control to regulate it for such a value in all system load conditions.

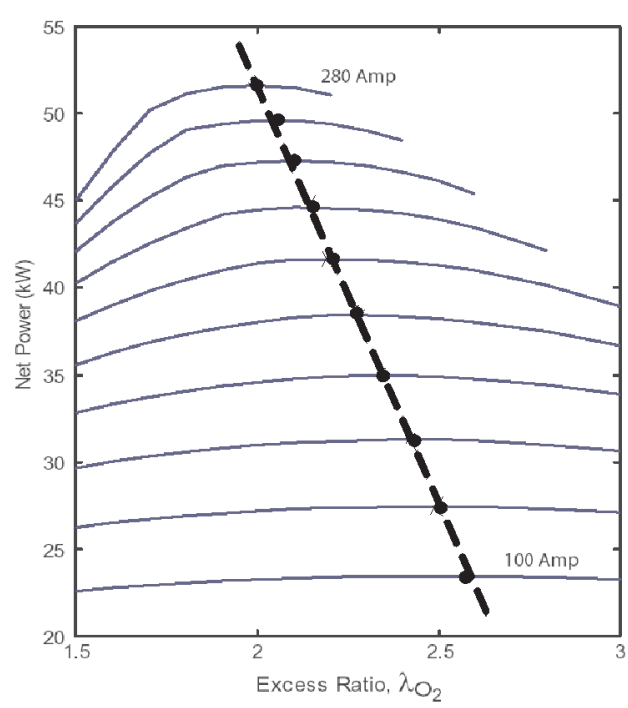

Fig. 1. System net power at different stack current and oxygen excess ratio [3]

Rys. 1. Zależność mocy netto ogniwa wysokociśnieniowego od wspótczynnika nadmiaru tlenu [3]

For the low-pressure cells, there is no information in the literature about the optimal values of an air excess coefficient from the viewpoint of net power and about the impact of a load on an optimum value. This encouraged the author to make an effort to clarify the issue.

\section{Test stand description}

The object of research was a Nexa fuel cell module (1.2 $\mathrm{kW}$ net power) placed in the Mechanical Department at the University of Trieste (Italy). In order to control the air output of the pump, a master-slave controller was constructed. A sub-controller, co-operating with the brushless motor speed regulator to change the air pump output, was introduced into the system to facilitate the tests. In parallel, another brushless motor was connected to the original controller's output. This solution enabled the researchers to test a variety of airflow control methods regardless of the procedures coded in the original controller (Fig. 2).

\section{Low-pressure fuel cells net power characteristics}

The experiment was carried out to answer the following questions:

- How does the fuel cell stack power (gross) increase as a result of increasing the airflow?

- How does the power necessary for an air pump drive increase as a result of increasing the airflow?

The responses will enable an obtainment of the characteristics of the dependency of the net power of the low-pressure spadek $\mathrm{P}_{n e} \mathrm{t}$ spowodowany zwiększonym zapotrzebowaniem mocy na napęd sprężarki $\mathrm{P}_{\mathrm{cm}}$. Zatem moc potrzebna do napędu sprężarki jest stratą bierną dla systemu ogniw paliwowych - równanie (3).

W niniejszym artykule uznano, że optymalny współczynnik nadmiaru powietrza $\lambda=2$ dla wybranej sprężarki i zastosowano sterowanie jednoparametryczne $\mathrm{w}$ celu regulacji na taką wartość we wszystkich warunkach obciążenia systemu.

W odniesieniu do ogniw niskociśnieniowych brak jest informacji w literaturze o optymalnych wartościach współczynnika nadmiaru powietrza z punktu widzenia mocy netto oraz o wpływie obciążenia na wartość optymalną. Dało to impuls do podjęcia wysiłku na rzecz wyjaśnienia tego problemu w niniejszej pracy.

\section{Stanowisko badawcze}

Obiektem badań był moduł ogniw paliwowych Nexa o mocy $1,2 \mathrm{~kW}$ znajdujący się na Wydziale Mechanicznym Uniwersytetu w Trieście (Włochy). W celu przeprowadzenia badań wykonano sterownik badawczy, który współpracując z regulatorem prędkości obrotowej silnika bezszczotkowego, zmieniał wydatek sprężarki powietrza. W tym samym czasie do wyjścia sterującego sterownika oryginalnego podłączono inny silnik bezszczotkowy. Takie rozwiązanie umożliwiło testowanie różnych metod sterowania wydatkiem powietrza bez względu na procedury zapisane na stałe w pamięci sterownika oryginalnego (rys. 2).

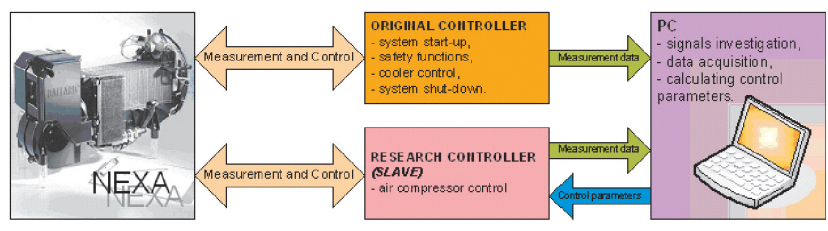

Fig. 2. The test bed information flow diagram

Rys. 2. Schemat przeplywu informacji na stanowisku badawczym

\section{Charakterystyka mocy netto niskociśnieniowego ogniwa paliwowego}

Eksperyment przeprowadzono w celu znalezienia odpowiedzi na pytania:

- Jak zwiększa się moc stosu (brutto) ogniw paliwowych wskutek zwiększenia strumienia przepływu powietrza?

- Jak zwiększa się moc potrzebna do napędu dmuchawy wskutek zwiększenia strumienia przepływu powietrza?

$\mathrm{Na}$ podstawie odpowiedzi możliwe będzie uzyskanie charakterystyki zależności mocy netto niskociśnieniowego ogniwa paliwowego typu PEM od współczynnika nadmiaru powietrza dla różnych obciążeń prądowych (rys. 3).

W wyniku badań eksperymentalnych wykonano charakterystykę wrażliwości generowanego przez niskociśnieniowe ogniwo paliwowe napięcia od wartości strumienia przepływającego powietrza dla różnych poziomów obciążenia prądowego systemu (rys. 4).

Nieznany również pozostaje model strat na napęd dmuchawy (silnika elektrycznego jak i samej dmuchawy), zwłaszcza w kontekście metod zasilania takiego silnika. 
PEM fuel cell on an air excess coefficient at different current loads (Fig. 3).

Basing on the experimental testing the most important characteristics of the fuel cell system were prepared (Fig. 4).

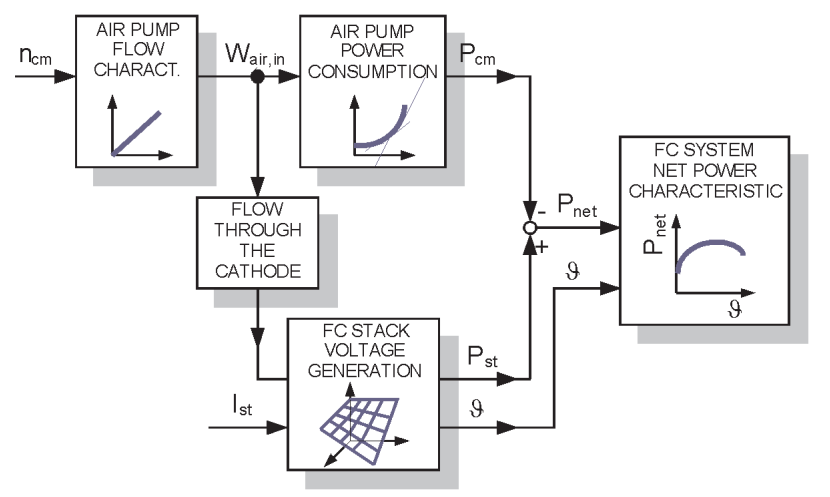

Fig. 3. Fuel cell stack block diagram

Rys. 3. Schemat blokowy stosu ogniw paliwowych

The loss model of a pump drive (both in an electric motor and the pump itself), especially in the context of the methods used to power such an engine, also remains unknown. Designing a test controller that cooperates with a rotational speed controller in a brushless pump motor, enabled to prepare the air pump power consumption characteristics depending on the airflow rate (Fig. 5).

The above results concerning the comparison of the power consumption by the brushless motor that operates with two different regulators make us aware of the reserve inherent in the effective control of different devices. The power consumption includes a regulator supply, too. The research regulator is commonly used in model-making and has been optimized for the power obtained and energy consumption. For this purpose, the PWM technique (Pulse Width Modulation) was used to control the sequences of the brushless engine. The original Nexa system controller does not use such a technique.

The results of tests $[9,10]$ indicated that for each stack current there exist optimal $\lambda$ by which maximal net power is obtained (Fig. 6). The research shows that the reactions occurring in a fuel cell need several times more air than is apparent from the theoretical demand.

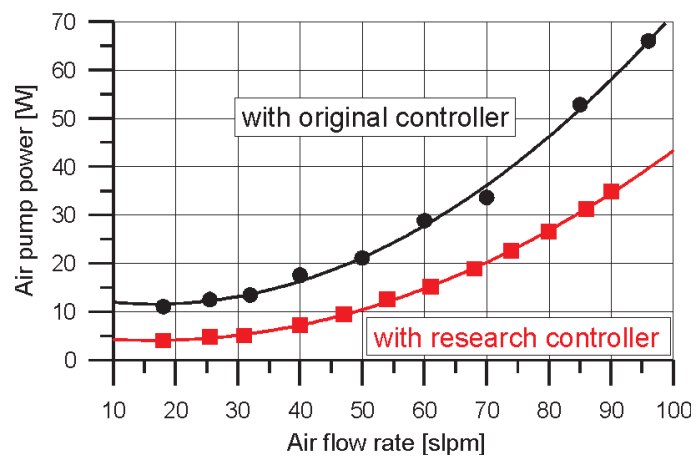

Fig. 5. Power consumed by air pump - electric motor group

Rys. 5. Zależność mocy pobieranej przez silnik pompy powietrza od wydatku powietrza
Wykonanie sterownika badawczego współpracującego z regulatorem prędkości obrotowej silnika bezszczotkowego dmuchawy powietrza umożliwiło wykonanie charakterystyki poboru mocy przez ten silnik w zależności od wydatku (rys. 5).

Przedstawione wyniki porównania poboru mocy przez silnik bezszczotkowy pracujący z dwoma rożnymi regulatorami uświadamiają rezerwy tkwiące w efektywnym sterowaniu różnymi urządzeniami. Pobór mocy uwzględnia również zasilanie regulatora. Regulator badawczy jest powszechnie używany w modelarstwie i został zoptymalizowany pod kątem osiąganej mocy i zużycia energii. W tym celu zastosowano w nim technikę PWM (zmiennego wypełnienia cyklu) w sterowaniu sekwencjami silnika bezszczotkowego. Regulator oryginalny systemu Nexa nie wykorzystuje takiej techniki.

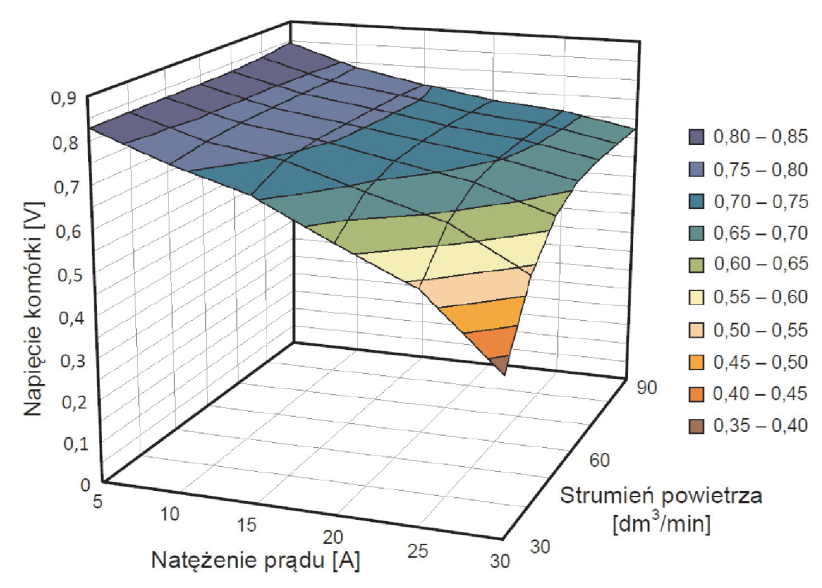

Fig. 4. Polarization surface of the fuel cell system Rys. 4. Płaszczyzna polaryzacji systemu ogniw [9]

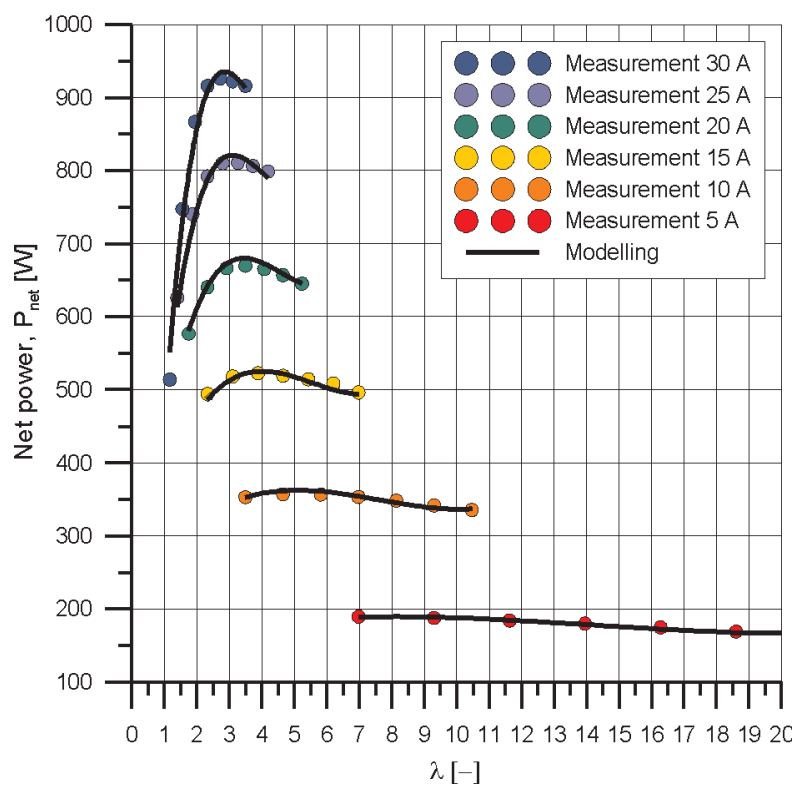

Fig. 6. The fuel cell stack system net power at different stack current and air excess coefficient $\lambda$

Rys. 6. Zależność mocy netto systemu ogniw paliwowych od wspótczynnika nadmiaru powietrza $\lambda$ dla różnych obciążen [9] 


\section{Adaptive algorithm}

The use of adaptive control with biparametrical identification enables us to adapt the control algorithm for an object, e.g. a particular copy of a fuel cell [6-8]. Therefore, such a control is called adaptive. Adaptation is needed when a designer, being uncertain, was not able to design an algorithm so that it could act optimally for a specific object and disturbances, or when an object changes and the data adopted during a design phase cease to be valid after a time.

Adaptive control represents an attempt to solve the problem of a quick returning of the controller [1] (Fig. 7). Thus, the aim of the adaptive control is to determine and maintain the top net power of the stack in any conditions of its operation, regardless of changes of the parameters of the object of control and its outer environment.

In this paper the fuel cell stack net power model is represented in the following relationship:

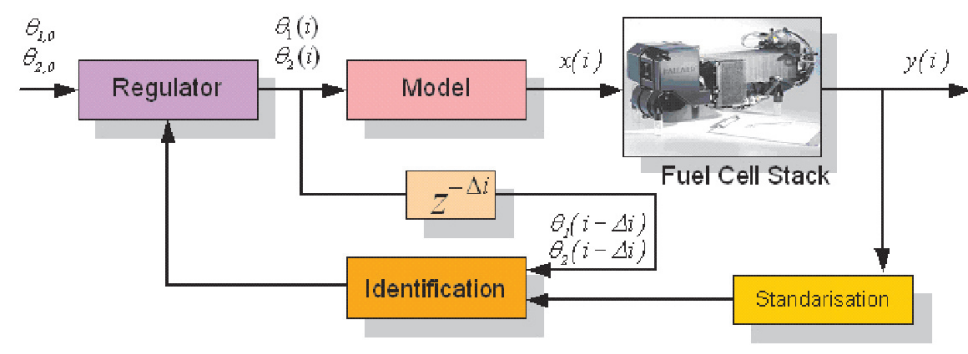

Fig. 7. Fuel cell stack adaptive control flowchart Rys. 7. Schemat adaptacyjnego sterowania ogniwem paliwowym

$$
\mathrm{x}_{\mathrm{opt}}=-\frac{\theta_{1}}{2 \cdot \theta_{2}}
$$

In this part of paper we will use the following descriptions: $\mathrm{y}=\mathrm{P}_{\text {net }}, \mathrm{x}=\mathrm{W}_{\text {air,in }}$.

The purpose of the algorithm is to determine (estimate) the value of $\theta_{1}$ and $\theta_{2}$ that ensure that a maximum net power is reached (Fig. 8).

For such a fuel cell stack model, the calculation of an adaptive control system is as follows:

$$
x(i)=-\frac{\theta_{1}(i-1)}{2 \cdot \theta_{2}(i-1)}+\zeta(\text { RND }-0.5)
$$

This is an estimate of the extremum location to which a perturbation signal is added (RND - random signal and $\zeta$ is perturbation signal).

If the characteristics of the system quality is modeled by a polynomial quadratic equation (3) the incremental method is very helpful - Fig. 9. A beneficial side effect of using the incremental method is that it removes one of the unknown parameters (y); this leaves just two parameters to estimate and makes the recursive estimation fast and more compact [5].
Badania wykazały $[9,10]$, że dla poszczególnych poziomów obciążenia prądowego stosu ogniw istnieje optymalna wartość strumienia powietrza, której odpowiada maksimum mocy netto (rys. 6). Z badań wynika, że do reakcji zachodzących w ogniwie paliwowym konieczne jest dostarczenie o wiele więcej powietrza niż to wynika $\mathrm{z}$ teoretycznego zapotrzebowania.

\section{Algorytm adaptacyjny}

Zastosowanie adaptacyjnego sterowania ekstremalnego z identyfikacją dwuparametryczną umożliwia dostosowanie algorytmu sterowania do obiektu, na przykład do konkretnego egzemplarza ogniwa paliwowego $[6,7,8]$. Dlatego sterowanie takie nazywa się adaptacyjnym. Adaptacja potrzebna jest wówczas, gdy z powodu niepewności projektant nie mógł zaprojektować algorytmu tak, by działał on w sposób optymalny dla konkretnego obiektu i zakłóceń lub gdy obiekt zmienia się i dane przyjęte na etapie projektowania po pewnym czasie przestają być aktualne.

Sterowanie adaptacyjne jest próbą rozwiązania problemu szybkiego przestrajania regulatora [1] - rys. 7. Zadaniem sterowania adaptacyjnego jest odnalezienie maksimum mocy netto systemu w każdych warunkach obciążenia, bez względy na zmieniające się właściwości zarówno samego systemu, jak i otoczenia zewnętrznego.

Model mocy netto wytwarzanej przez stos ogniw paliwowych jest zapisany za pomocą zależności (3).

Zadaniem algorytmu sterowania jest wyznaczenie (estymacja) takich wartości współczynników $\theta_{1}$ i $\theta_{2}$, które odpowiadają maksymalnej mocy netto (rys. 8) - wzór (4).

Na podstawie modelu obliczane jest sterowanie optymalne - równanie (5), gdzie: RND - wartość losowa z zakresu 0-1 o równym prawdopodobieństwie wystąpienia poszczególnych wartości, i - indeks kolejnych kroków czasowych, $\zeta$ - współczynnik wielkości zaburzania wielkości sterującej x(i).

Gdy charakterystyka właściwości systemu jest modelowana przez równanie kwadratowe (3), bardzo pomocne jest skorzystanie z metody przyrostowej - rys. 9. Zastosowanie jej pozwala na zmniejszenie ilości niewiadomych

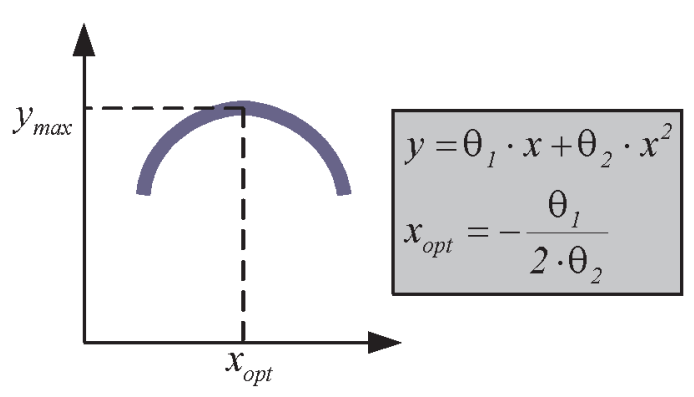

Fig. 8. Finding the maximum of exponential function of the second order

Rys. 8. Sposób wyznaczania maksimum funkcji wykładniczej drugiego stopnia 
In he presented method (see also Fig. 9):

$$
\begin{aligned}
\Delta \hat{y}(i) & =\hat{y}(i)-y(i-1) \\
\Delta x(i) & =x(i)-x(i-1) \\
\Delta x^{2}(i) & =x^{2}(i)-x^{2}(i-1)
\end{aligned}
$$

The estimated result of the increment of the maximum net power in this step should obviously equal the desirable value:

$$
\Delta \hat{y}(i)=\theta_{1}(i-1) \cdot \Delta x(i)+\theta_{2}(i-1) \cdot \Delta x^{2}(i)
$$

The value of $\hat{y}(i)$ is obtained from a current model calculation:

$$
\begin{aligned}
& \hat{y}(i)=y(i-1)+\theta_{1}(i-1) \cdot \Delta x(i)+ \\
& +\theta_{2}(i-1) \cdot \Delta x^{2}(i)+\zeta(R N D-0,5)
\end{aligned}
$$

In the same time the real value $y(\mathrm{i})$ is measured. Control error is calculated on its basis:

$$
e(i)=y(i)-\hat{y}(i)
$$

and then, the "knowledge" of the adaptive system is updated:

$$
\begin{gathered}
L_{1}=P_{11}(i-1) \cdot x(i)+P_{12}(i-1) \cdot x^{2}(i) \\
L_{2}=P_{21}(i-1) \cdot x(i)+P_{22}(i-1) \cdot x^{2}(i) \\
1=L_{1} \cdot x(i)+L_{2} \cdot x^{2}(i) \\
K_{1}=\frac{L_{1}}{\beta+1} \\
\theta_{1}(i)=\theta_{1}(i-1)-K_{1} \cdot e(i) \\
\theta_{2}(i)=\theta_{2}(i-1)-K_{2} \cdot e(i) \\
\mathrm{K}_{11}=\frac{L_{2}}{\beta+1} \\
P_{22}(i)=\frac{P_{11}(i-1)-\frac{L_{1}^{2}}{\beta+1}}{\beta} \\
P_{12}(i)=\frac{P_{12}(i-1)-\frac{L_{1} \cdot L_{2}}{\beta+1}}{\beta} \\
\beta
\end{gathered}
$$


Basing on the model, the new optimal control for the next time step is calculated:

$$
x(i+1)=-\frac{\theta_{1}(i)}{2 \cdot \theta_{2}(i)}+\zeta(R N D-0.5)
$$

\section{Experimental results}

The experiment began with inputting values $\theta_{1}$ and $\theta_{2}$ that were far from values appropriate for the current working point. This enforced an increase of the air supply (above 80 $1 / \mathrm{min}$ ) i.e. increase of the air pump motor speed. Successively, the algorithm decreased the air supply to the level corresponding to the maximum power under said stack current.

The rate of finding of the optimal $\lambda$ value depends mainly on the value of forgetting factor $\beta$ which characterizes the operation of an adaptive algorithm (Fig. 10).

The time required by the algorithm to determine the optimal value of $\lambda$ depends on forgetting factor $\beta$. Low value of forgetting factor $\beta$ allows quick response to sudden change of load, but simultaneously causes reaction to noise - which results in instability under stable load. High value of forgetting factor $\beta$ gives noise immunity but significantly increases time of reaction to sudden change of working conditions (Fig. 10). Therefore, the value of forgetting factor $\beta$ must be a compromise between speed and stability (Fig. 11).

The adaptive algorithm has got many variables and signals that support an estimation process. The quality and speed of finding an optimal point depends on their values. These variables and signals include even a disturbing signal value (Fig. 12). In practice, these disturbances are necessary to ensure the sustainable stimulation of an estimation process. A measured noise and other disturbances occurring in a real research stand are too small to sustain the process of correct estimation. Learning the algorithm could be stopped with no additional disturbances to occur.

Also, the incidence of new control value generation affects the speed of system performance (Fig. 13). This value depends on the time constant of the entire fuel cell system, and this, in turn, on a current system state and environment conditions.

However, extreme control takes time to find optimal operating points. In the case of using step current load the system needs tens of seconds to adapt to new conditions (Fig. 14). If a fuel cell module cooperates with devices that have various current consumption, it causes a very significant loss of control. In order to reduce the time necessary for the adaptive algorithm to find a maximum net power point, one can use an array method (a static map) or dependency as a function that would include the approximate dependency of the position of an optimal point on the load. In this case,
Szybkość odnajdowania wartości optymalnej współczynnika $\lambda$ zależy głównie od współczynnika szybkości uczenia się $\beta$, który charakteryzuje pracę algorytmu adaptacyjnego - rys. 10 .

Wartość współczynnika $\beta$ ma ogromny wpływ na właściwości regulatora a tym samym na jakość regulacji. Dla małej wartości $\beta$ algorytm regulacji działa bardzo „,nerwowo", jednak czas potrzebny do odnalezienia optimum jest krótki. Praca układu z większymi współczynnikami $\beta$ charakteryzuje się większą stabilnością i odpornością na wszelkiego rodzaju zakłócenia w stanach ustalonych (rys. 11). W stanach dynamicznych algorytmy te są wolniejsze, co skutkuje dłuższym okresem osiągania stabilizacji.

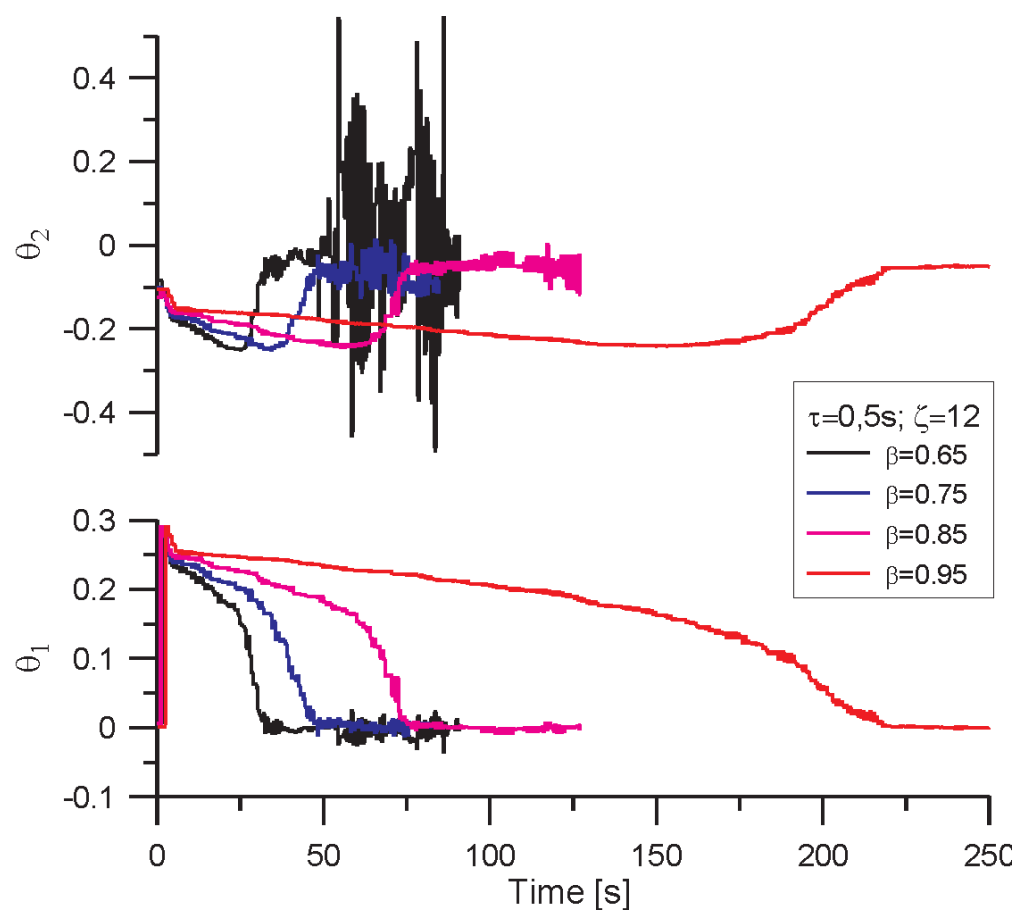

Fig. 11. Parameters estimation for an adaptive optimizer with two parameters Rys. 11. Wpływ współczynnika $\beta$ na stabilność estymowanych parametrów

W algorytmie adaptacyjnym istnieje wiele zmiennych i sygnałów wspomagających proces estymacji. Od ich wartości zależy jakość i szybkość odnajdywania punktu optymalnego. Można do nich zaliczyć chociażby wartość sygnału zaburzającego (rys. 12). W praktyce zaburzenia te są niezbędne w celu zapewnienia trwałego pobudzania procesu estymacji. Szum pomiarowy i inne zakłócenia występujące na rzeczywistym stanowisku badawczym są zbyt małe by podtrzymać proces poprawnej estymacji. Bez dodatkowych zaburzeń procesu uczenia się algorytm mógłby zostać zatrzymany.

Także częstość generowania nowej wartości sterującej ma wpływ na szybkość działania układu (rys. 13). Ta wartość zależy od stałej czasowej całego systemu ogniw paliwowych, zaś ta z kolei od aktualnego stanu systemu i warunków otoczenia.

Jednak sterowanie ekstremalne wymaga długiego czasu na odnalezienie optymalnych punktów pracy (rys. 14). Przy 


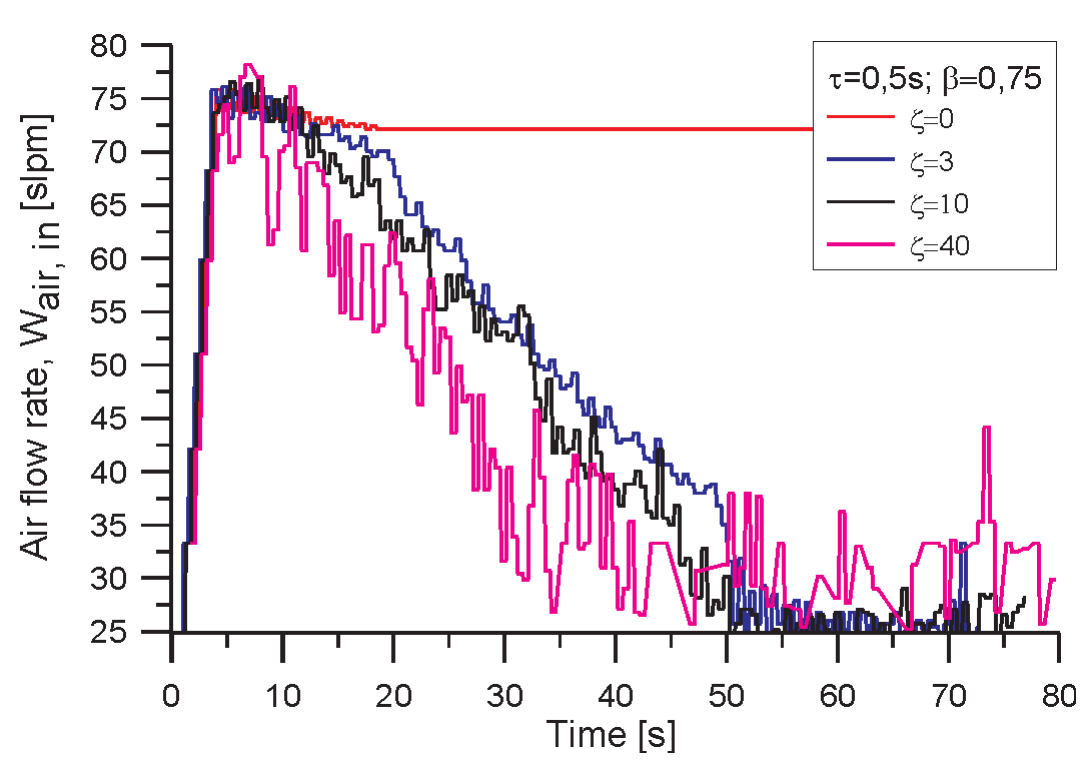

Fig. 12. Illustrating the improved tuning performance with variable test perturbation amplitude

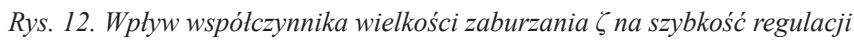

the algorithm does not have to cover the whole distance related to the change of load while identifying $\theta_{1}$ and $\theta_{2}$ parameters for all intermediate states. Its fine-tuning would already occur in a very narrow range of mass flow changes in an air blower.

The original system controls the mass flow of an air pump in an open loop, depending on the current load. This allows almost an immediate response by an air pump to a stroke of load (a time delay is about 1 second for a stroke within the range from idle to maximum speed). In this case, the author suggests updating the characteristics of the dependency of the air blower mass flow on the current charged from the cell. The first update would level the differences resulted from the discrepancies in the cell properties after leaving a production line. Subsequent updates performed, e.g. every 50 hours, would take into account object aging. The possibility of re-calibration when ambient conditions (temperature, pressure variation associated with the elevation above sea level and humidity) change is also assumed here. People using a fuel cell as portable (tourist) power generators would gain advantage from such an opportunity.

Characteristics updating would be a several minute test during which the system would calibrate algorithm parameters. The extreme control could be, of course, used for self-calibration. The open-loop control with the possibility of updating the mass flow in an air pump would enable a rapid system response in dynamic states and its work in the area very close to the maximum net power (obviously depending on the update characteristics frequency). zastosowania skokowego obciążenia układ potrzebuje kilkadziesiąt sekund na przystosowanie się do nowych warunków. W przypadku pracy modułu ogniw paliwowych z urządzeniami, które charakteryzuje zmienny pobór prądu, powoduje to bardzo duże straty sterowania. W celu skrócenia czasu odnajdywania punktu z maksymalną mocą netto przez algorytm adaptacyjny można zastosować metodę tablicową (mapę) lub wprowadzenie zależności w postaci funkcji, która zawierałaby przybliżoną zależność położenia punktu optymalnego od obciążenia. W tej sytuacji algorytm nie musiałby pokonywać całej drogi związanej ze zmianą obciążenia, identyfikując parametry $\theta_{1}$ i $\theta_{2}$ dla wszystkich stanów pośrednich. Jego dostrojenie występowałoby już w bardzo niewielkim przedziale zmian wydatku dmuchawy powietrza.

System oryginalny steruje wydatkiem dmuchawy powietrza w pętli otwartej w zależności od obciążenia prądowego. Umożliwia to prawie natychmiastową odpowiedź dmuchawy na skok obciążenia (zwłoka czasowa wynosi ok. $1 \mathrm{~s}$ dla skoku od prędkości biegu jałowego do prędkości maksymalnej). W takiej sytuacji autor proponuje uaktualnianie charakterystyki zależności wydatku dmuchawy powietrza od pobieranego z ogniwa prądu. Pierwsza aktualizacja miałaby niwelować różnice wynikające z rozbieżności właściwości ogniwa po wyjściu $\mathrm{z}$ taśmy produkcyjnej. Kolejne aktualizacje przeprowadzane np. co 50 godzin pracy uwzględniałyby starzenie obiektu. Zakłada się także możliwość przeprowadzenia ponownej kalibracji podczas zmiany warunków otoczenia (temperatura, zmiana ciśnienia związana z położeniem nad poziomem morza, wilgotność). Ta ewentualność byłaby przydatna dla

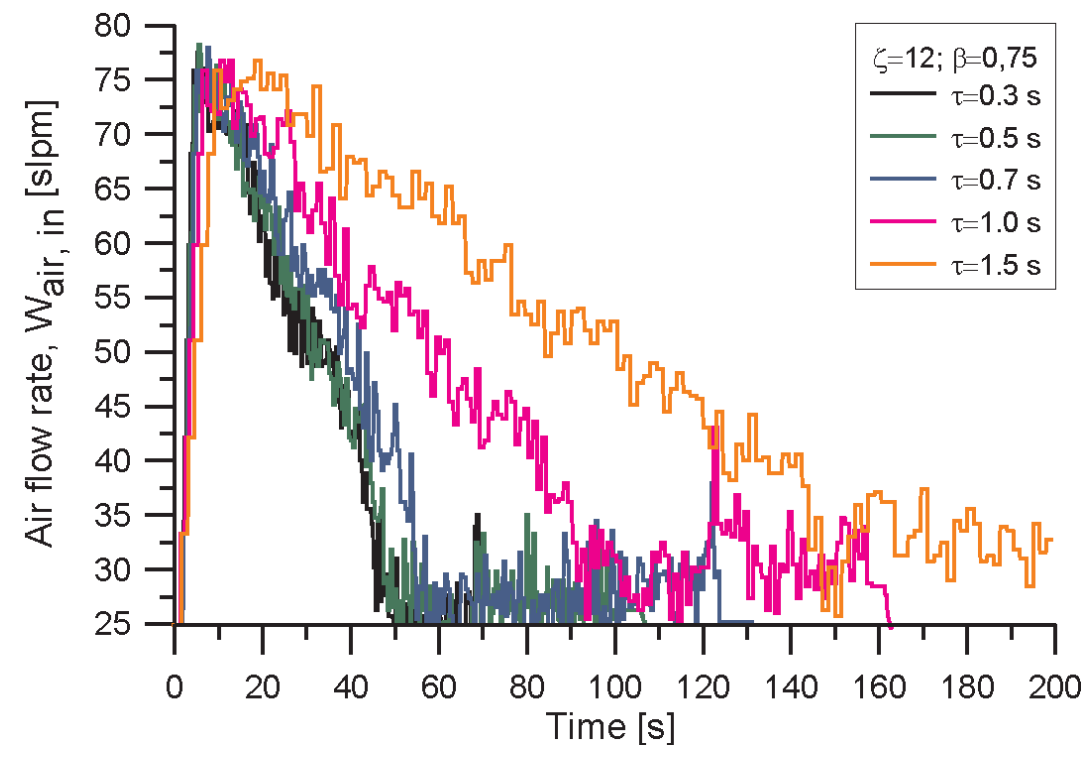

Fig. 13. Relationship between control step-time $\tau$ and lag of the controller response Rys. 13. Wpływ częstości generowania nowej wartości sterującej $\tau$ na szybkość regulacji 


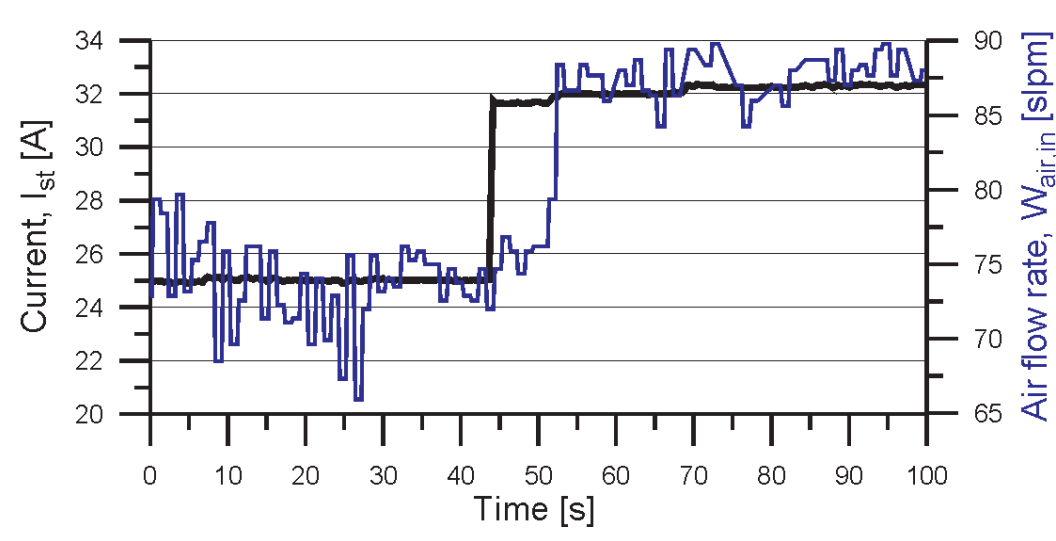

Fig. 14. Adaptive system response for positive current jump 25-32 A for $\beta=0.75$ Rys. 14. Odpowiedź systemu na skok obciążenia 25-32 A dla $\beta=0,75$

osób wykorzystujących ogniwo paliwowe jako turystyczny agregat prądotwórczy. Aktualizacja charakterystyki polegałaby na wykonaniu kilkuminutowego testu, podczas którego system dokonałby kalibracji współczynników wielomianu. Do przeprowadzenia autokalibracji można wykorzystać zaproponowane sterowanie ekstremalne. Sterowanie w pętli otwartej z możliwością uaktualniania charakterystyki wydatku dmuchawy powietrza umożliwiłoby szybką reakcję systemu w stanach dynamicznych i pracę w obszarze bardzo bliskim maksymalnej mocy netto (zależnym oczywiście od częstości aktualizacji charakterystyki).

\section{Conclusion}

In the paper airflow control of the PEM fuel cell was presented in order to find and hold the maximal value of the net power produced by the fuel cell stack, regardless of the changes of the parameters of the object of control and its ambient environment. The application of an adaptive extremum control with bi-parameter identification provides automatic adjustment of the parameters of a controller to the changing characteristics of an object. The adaptive algorithm contains a number of variables and signals that support the estimation process. The quality and speed of finding of an optimal point depends on their values.

\section{Podsumowanie}

W artykule opisano sterowanie powietrzem zasilającym ogniwo w celu określenia i stabilizacji pracy systemu w punkcie maksymalnej mocy netto, bez względu na zmieniające się właściwości ogniwa paliwowego i jego otoczenia. Zastosowanie adaptacyjnego sterowania ekstremalnego z identyfikacją dwuparametryczną umożliwia dostosowanie się algorytmu sterowania do aktualnej charakterystyki ogniwa paliwowego. W algorytmie adaptacyjnym istnieje wiele zmiennych i sygnałów wspomagających proces estymacji. Jak wykazano w artykule, od ich wartości zależy jakość i szybkość odnajdywania punktu optymalnego.

\section{Bibliography/Literatura}

[1] Niedźwiedzki M.: Identyfikacja niestacjonarnych obiektów losowych. Zeszyty Naukowe Politechniki Gdańskiej, Elektronika 69, Gdańsk 1990

[2] Pukrushpan J., Peng H., Stefanopoulou A.: Simulation and analysis of transient fuel cell system based on dynamic reactant flow model, Proceedings of IMECE'02, 2002 ASME International Mechanical Engineering Congress \& Exposition, November 17-22, 2002, New Orleans, Louisiana, USA, IMECE2002-DSC-32051.

[3] Tekin M., Hissel D., Pera M., Kauffmann J.: Energy consumption reduction of a PEM fuel cell motor-compressor group thanks to efficient control laws, Journal of Power Sources, 156 (2006), 57-63.

[4] Vahidi A., Stefanopoulou A., Peng H.: Model Predictive Control for Starvation Prevention in a Hybrid Fuel Cell System, IEEE Proceedings of 2004 American Control Conference, 2004.

[5] Wellstead P.E., Scotson P.G.: Self-tuning extremum control, IEE Proceedings, Vol. 137, Pt. D, No. 3, May 1990.

[6] Wendeker M., Taccani R., Malek A., Czarnigowski J.: Adaptive control of the fuel cell system, International Conference HYPOTHESIS V, 7-10 September 2003, Porto Conte, Sardinia, Italy, 717-726, 2003.
[7] Wendeker M., Malek A., Czarnigowski J., Taccani R., Boulet P., Breaban F.: Adaptive airflow control of the PEM fuel cell system, SAE 2007-01-2012. 2007 JSAE/SAE International Fuels \& Lubricants Meeting, 23-26.07.2007, Kyoto, Japan.

[8] Zhong Z., Huo H., Zhu X., Cao G., Ren Y.: Adaptive maximum power point tracking control of fuel cell power plants, Journal of Power Sources, 176, 259-269 (2008).

[9] Małek A.: Sterowanie przepływem powietrza w niskociśnieniowym ogniwie paliwowym typu PEM. Rozprawa doktorska, Politechnika Lubelska, Lublin 2010.

[10] Małek A., Wendeker M.: Ogniwa paliwowe typu PEM - teoria i praktyka. Politechnika Lubelska, Lublin 2010.

Małek Arkadiusz, DEng. - doctor in the College of Enterprise and Administration in Lublin, researcher in the Faculty of Mechanical Engineering at Lublin University of Technology,

Dr inż. Arkadiusz Małek - wyktadowca w Wyższej Szkole Przedsiębiorczości i Administracji w Lublinie, pracownik naukowy na Wydziale Mechanicznym Politechniki Lubelskiej.

e-mail:arkadiusz.malek@wp.pl 